\title{
Source Tracking and Carcinogenic Risk of Polycyclic Aromatic Hydrocarbons in Contaminated Farmlands of Egi, Niger Delta, Nigeria
}

\author{
Elechi Owhoeke*, Michael Horsfall Jnr, Charles Ikenna Osu \\ Department of Pure and Industrial Chemistry, Faculty of Science, University of Port Harcourt, Port Harcourt, Nigeria \\ Email address: \\ elechiowhoeke@yahoo.com (E. Owhoeke), michael.horsfall@uniport.edu.ng (M. H. Jnr), charsike@yahoo.com (C. I. Osu) \\ ${ }^{*}$ Corresponding author
}

\section{To cite this article:}

Elechi Owhoeke, Michael Horsfall Jnr, Charles Ikenna Osu. Source Tracking and Carcinogenic Risk of Polycyclic Aromatic Hydrocarbons in Contaminated Farmlands of Egi, Niger Delta, Nigeria. Journal of Drug Design and Medicinal Chemistry. Vol. 5, No. 4, 2019, pp. 61-66. doi: $10.11648 /$ j.jddmc.20190504.12

Received: October 20, 2019; Accepted: November 4, 2019; Published: January 6, 2020

\begin{abstract}
The levels of Polycyclic Aromatic Hydrocarbons (PAHs) in contaminated farmland soil from three oil-producing communities (Oboburu, Obagi, and Ogbogu) in Egi, Niger Delta were assessed for variability, origin and health risks. The result showed that $\mathrm{tPAHs}$ of Oboburu were $1344 \pm 1685 \mathrm{mg} / \mathrm{kg}$ for carcinogenic while BaP $(257.3 \pm 270.5 \mathrm{mg} / \mathrm{kg}) \mathrm{had}$ the greatest value. Obagi had $4154 \pm 3461 \mathrm{mg} / \mathrm{kg}$ for cPAHs with BkF $(861.5 \pm 543.7 \mathrm{mg} / \mathrm{kg})$ having the greatest amount. Ogbogu was $354.7 \pm 360.7 \mathrm{mg} / \mathrm{kg}$ for total cPAHs while BgP $(104.1 \pm 141.8 \mathrm{mg} / \mathrm{kg})$ had highest amount. The dominant PAHs were BbF, $\mathrm{BkF}, \mathrm{DbA}, \mathrm{BaP}$, IdP and BgP. The principal component analysis (PCA) indicated that the PAHs were majorly of pyrogenic and petrogenic origin. The predicted risk due to PAHs in soil for children showed tPAHs was $1.68 \mathrm{E}-2$, with high risk for $\mathrm{BaP}$ (9.05E-3), IdP (5.05E-3), BbF (1.63E-3) and BkF (1.04E-3), while the adults estimation showed tPAHs was 1.13E-2 and high risk were for BaP (2.30E-3), IdP (1.08E-3) and BkF (2.57E-4). These values are more than the limit of the US EPA risk management criterion $\left(10^{-6}\right.$ to $\left.10^{-4}\right)$ where management decisions should be considered. The trend indicated that their presence in the environment makes it unsafe for the dwellers.
\end{abstract}

Keywords: PAHs, Sources, Risk, Contamination, Egi

\section{Introduction}

Egi is a clan made up of sixteen (16) communities in the southern part of Ogba/Egbema/Ndoni LGA of Rivers, Nigeria. The Egi people are predominantly peasant farmers with little fishing and craft work like the moulding of clay pots, baskets, fishnet, thatches, and others. Apart from peasantry farming, crude oil mining is another activity which has been going on the area dating back from the 60s. This activity (oil and gas mining) has impacted negatively on the arable land of the people. The spillage comes from leakages, seepages, equipment damages, and failures before been released to the environment which have both immediate and remote effects on both inhabitants and other forms of lives within the environment [1].

One of the main environmental impacts of the industry on the study area is the progressive change in the chemical composition of ecosystems located around emission sources. Incessant release of heavy metals from anthropogenic sources causes significant changes in the biogeochemical cycle of those elements. Soil contamination is mostly due to contaminants released from point sources, as it has been shown in studies in developing countries that have petroleum and natural gas as their main natural resource.

This study was undertaken to identify the sources and risks of 16 USEPA Polycyclic Aromatic Hydrocarbons in contaminated soil samples from farmlands in Egi oil-producing communities of Rivers State in the Niger Delta of Nigeria.

\section{Materials and Methods}

\subsection{Description of Study Area}

The samples for this work were collected from crude oil contaminated farmland soil, within Egi communities of 
Obagi, Ogbogu, and Oboburu all in Ogba/Egbema/Ndoni local government area (ONELGA) of Niger Delta, Nigeria. While Ase-azaga in ONELGA served as the control. The local government stretches from longitude $6^{\circ} 28^{\prime} 13^{\prime \prime} \mathrm{E}$ through longitude $6^{\circ} 47^{\prime} 34^{\prime \prime} \mathrm{E}$ and latitude $5^{\circ} 9{ }^{\prime} 42^{\prime \prime} \mathrm{N}$ through $5^{\circ} 44^{\prime} 3^{\prime \prime} \mathrm{N}$. Egi land is a major oil-producing area of the Niger Delta of Nigeria. The area of study play host to two multinational oil companies Total Exploitation and Production Limited (EPNL) and Nigerian Agip Oil Company (NAOC) [2].

\subsection{Sample Collection}

In each of the selected sites, six quadrats were marked. In each quadrat, four core soil samples were collected randomly at depth 0-20 cm using a soil auger and put together to form a composite sample. The composite samples were wellmixed and sub-samples taken. Four soil replicates were collected from each site of the contaminated soil of the study area. The soil samples were kept in zip-locked plastic bags, labelled and transported to the laboratory for further treatment and analysis.

\subsubsection{Sample Preparation}

The samples were dried with the help of air and sun, they were then homogenized having been previously ground and sieved through sieves of stainless steel $2 \mathrm{~mm}$ mesh. All other analysis was conducted through samples prepared in this way.

\subsubsection{Extraction and Gas Chromatography Analysis}

A $10 \mathrm{~g}$ sample was extracted with a mixture of Dichloromethane (DCM)/Acetone solvent, Sodium Sulphate was added to remove any trapped water molecule in the sample extract. The extract is concentrated by evaporation in a mechanical shaker for GC analysis of Polycyclic Aromatic Hydrocarbons (PAHs) using Gas Chromatography-Flame Ionization Detector (GC FID).

\subsection{Carcinogenic Risk}

The possibility of cancer incidences due to exposure to the possible carcinogen or mutagen is indicated by cancer risk assessment [3]. The Incremental Lifetime Cancer Risk (ILCR) model [4] was used to estimate the risk of people exposed to PAHs in soil. The estimated daily intake (EDI) of PAHs represents the PAHs in soil samples ingested into the body system represented by EDI. The EDI $(\mathrm{mg} / \mathrm{kg} / \mathrm{d})$ of PAHs through soil ingestion was calculated using the following formulae [4-6].

$$
E D I=\frac{C S \times I R \times C F \times E D \times E F}{B w \times A T}
$$

where EDI is the Estimated daily intake related to soil particle ingestion $(\mathrm{mg} / \mathrm{kg} / \mathrm{d}), \mathrm{SF}$ is the sum of converted PAH concentrations in soil based on toxic equivalents (TEF) of $\mathrm{BaP}(\mathrm{mg} / \mathrm{kg}), \mathrm{IR}$ is soil ingestion rate $(\mathrm{m} / \mathrm{gd}), \mathrm{EF}$ stands for exposure frequency (day/year), ED represent exposure duration (year), BW is for body weight of the exposed individual $(\mathrm{kg})$, AT is an averaging time of 365 days per year for 70 years for lifetime exposure of cancer risk $(70$ years $\times$ 365 days/year), CF denotes conversion factor $\left(1 \times 10^{-6} \mathrm{~kg} / \mathrm{mg}\right)$.

$$
\text { Cancer Risk }=\mathrm{SF} \times \mathrm{EDI}
$$

$\mathrm{CSF}=$ cancer slope factor $(\mathrm{mg} / \mathrm{kg} / \mathrm{day})^{-1}$.

Cancer risk (CR) can be defined as the upper bound lifetime probability of an individual's developing cancer because of contact to a potential carcinogen [7].

The incremental lifetime cancer risk (ILCR) of the studied population attributable to PAHs daily intake was estimated with the following parameters in the table below.

Table 1. Parameters used in cancer risk assessment.

\begin{tabular}{llll}
\hline Definition & & Age limit & Unit \\
\hline & 10 & 60 & Years \\
Ingestion Rate (IR) & 200 & 100 & $\mathrm{mg} /$ day \\
Exposure Frequency (EF) & 180 & 180 & Days \\
Body Weight (BW) & 30 & 60 & $\mathrm{Kg}$ \\
Average Time (AT) & 3650 & 21900 & Days \\
Exposure Duration (ED) & 10 & 60 & Years \\
CS & & & \\
Conversion Factor (CF) & $10^{-6}$ & $10^{-6}$ & $\mathrm{mg}$ to kg \\
\hline
\end{tabular}

[8].

\subsection{Statistical Analysis}

Excel 2010 (Microsoft Office, Microsoft,) was used to calculate the descriptive statistics. SPSS software (version 16, SPSS, Chicago, IL, USA) was applied for the multivariate statistical analyses, which calculated the Principal Component Analysis (PCA) and correlational matrix.

\section{Results and Discussion}

\subsection{Distribution of PAHs in Contaminated Soil Samples}

The results of PAHs concentrations in the soil samples from the study area are presented in Tables 2 and 3.

Table 2. Mean of non-carcinogenic PAHs $(\mathrm{mg} / \mathrm{kg})$ in contaminated soils of the study area.

\begin{tabular}{lllllll}
\hline PAHs & & Oboburu & Obagi & Ogbogu & Ase-azaga & USEPA [6] \\
\hline \multirow{2}{*}{ Nap } & Mean & $0.089 \pm 0.104$ & $52.70 \pm 73.48$ & $1.760 \pm 2.961$ & $0.003 \pm 0.000$ \\
& Range & $0.001-0.256$ & $0.004-178.0$ & $0.006-6.888$ & 0.14 \\
Ace & Mean & $5.535 \pm 9.140$ & $157.6 \pm 233.6$ & $4.810 \pm 7.364$ & $0.041 \pm 0.021$ \\
& Range & $0.012-21.36$ & $0.195-561.0$ & $0.100-17.63$ & 3.40 \\
Acn & Mean & $8.728 \pm 14.20$ & $120.0 \pm 172.7$ & $9.115 \pm 15.42$ & BDL \\
& Range & $0.028-33.30$ & $0.246-418.2$ & $0.098-35.83$ & & \\
Flo & Mean & $6.538 \pm 6.770$ & $135.9 \pm 153.7$ & $3.730 \pm 5.843$ & $0.050 \pm 0.001$ \\
Phe & Range & $0.195-16.60$ & $1.909-395.1$ & $0.317-13.85$ & 2.3 & \\
\end{tabular}




\begin{tabular}{|c|c|c|c|c|c|c|}
\hline PAHs & & Oboburu & Obagi & Ogbogu & Ase-azaga & USEPA [6] \\
\hline \multirow{3}{*}{ Ant } & Range & $0.133-27.75$ & $8.320-814.1$ & $0.275-14.91$ & & \\
\hline & Mean & $62.70 \pm 77.31$ & $190.6 \pm 246.4$ & $5.408 \pm 5.930$ & $\mathrm{BDL}$ & 17 \\
\hline & Range & $2.471-192.4$ & $19.16-615.7$ & $1.187-9.660$ & & \\
\hline \multirow{2}{*}{ Flu } & Mean & $21.34 \pm 23.96$ & $502.5 \pm 525.7$ & $4.038 \pm 2.472$ & $0.245 \pm 0.052$ & 2.3 \\
\hline & Range & $1.851-61.96$ & $25.95-1391$ & $1.130-7.617$ & & \\
\hline \multirow{2}{*}{ Pyr } & Mean & $40.88 \pm 46.00$ & $122.2 \pm 98.05$ & $9.650 \pm 12.69$ & $0.004 \pm 0.001$ & 1.7 \\
\hline & Range & $1.069-115.9$ & $22.14-273.8$ & $1.485-31.60$ & & \\
\hline \multirow{2}{*}{$\mathrm{BgP}$} & Mean & $156.0 \pm 154.4$ & $280.5 \pm 362.8$ & $104.1 \pm 141.8$ & $0.043 \pm 0.006$ & - \\
\hline & Range & $15.53-406.9$ & $34.54-907.2$ & $7.754-349.0$ & & \\
\hline tPAHs & & $312.0 \pm 342.8$ & $1795 \pm 2202$ & $147.1 \pm 200.5$ & $2.227 \pm 0.493$ & 26.84 \\
\hline
\end{tabular}

The total PAHs for Oboburu was $312.0 \pm 342.8 \mathrm{mg} / \mathrm{kg}$, with $\operatorname{BgP}(156.0 \pm 154.4 \mathrm{mg} / \mathrm{kg})$, Ant $(62.72 \pm 77.31 \mathrm{mg} / \mathrm{kg})$ and Flu $(21.34 \pm 23.96 \mathrm{mg} / \mathrm{kg})$ had the greatest mean, while Obagi had tPAHs of $1795 \pm 2202 \mathrm{mg} / \mathrm{kg}$ and $\mathrm{BgP}(280.5 \pm 362.8 \mathrm{mg} / \mathrm{kg})$, Flu $(502.5 \pm 525.7 \mathrm{mg} / \mathrm{kg})$ and Phe $(233.3 \pm 335.9 \mathrm{mg} / \mathrm{kg})$ with highest value. Ogbogu had total of $147.1 \pm 200.5 \mathrm{mg} / \mathrm{kg}$ and $\mathrm{BgP}(104.1 \pm 141.8 \mathrm{mg} / \mathrm{kg})$ had the greatest amount. The impact levels were Obagi $>$ Oboburu $>$ Ogbogu. This indicates high pollution which could be caused by improper monitoring of oil spill remediation activities. The mean of PAHs from the three communities was higher than the USEPA limit which is $26.84 \mathrm{mg} / \mathrm{kg}$. The level of contamination is not far from the extensive drilling activities going on in the area of study.
Some of the cancer causing PAHs were detected in the soil samples examined with values very high. The average value of these PAHs varied considerably across the three areas. The total PAHs for Oboburu was $1344 \pm 1685 \mathrm{mg} / \mathrm{kg}$, while BkF $(371.0 \pm 566.1 \mathrm{mg} / \mathrm{kg}), \mathrm{BaP}(257.3 \pm 270.5 \mathrm{mg} / \mathrm{kg})$ and $\mathrm{DaA}$ $(257.5 \pm 300.7 \mathrm{mg} / \mathrm{kg})$ had high amount. Obagi had the highest impact, the total mean was $4154 \pm 3461 \mathrm{mg} / \mathrm{mg}$ with $\mathrm{BkF}(861.5 \pm 543.7 \mathrm{mg} / \mathrm{kg}), \mathrm{BaP}(819.5 \pm 511.0 \mathrm{mg} / \mathrm{kg})$ and Chr $(570.0 \pm 651.9 \mathrm{mg} / \mathrm{kg})$ having highest average. Ogbogu was total PAHs $354.7 \pm 360.7 \mathrm{mg} / \mathrm{kg}$, while IdP $(104.9 \pm 141.3$ $\mathrm{mg} / \mathrm{kg}), \mathrm{BaP}(74.88 \pm 68.70 \mathrm{mg} / \mathrm{kg})$ and $\mathrm{BkF}(50.03 \pm 63.38$ $\mathrm{mg} / \mathrm{kg}$ ). The level of impact was in the order of Obagi $>$ Oboburu $>$ Ogbogu.

Table 3. Mean of carcinogenic PAHs $(\mathrm{mg} / \mathrm{kg})$ in contaminated soils of the study area.

\begin{tabular}{|c|c|c|c|c|c|c|}
\hline PAHs & & Oboburu & Obagi & Ogbogu & Ase-azaga & USEPA 2009 \\
\hline \multirow{2}{*}{$\mathrm{BaA}$} & Mean & $119.5 \pm 155.9$ & $507.5 \pm 484.9$ & $17.02 \pm 12.03$ & $0.562 \pm 0.321$ & $1.5 \mathrm{E}-4$ \\
\hline & Range & $2.744-383.7$ & $48.68-1318$ & $8.458-27.57$ & & \\
\hline \multirow{2}{*}{ Chr } & Mean & $136.7 \pm 193.5$ & $570.0 \pm 651.9$ & $33.00 \pm 29.78$ & $0.450 \pm 0.045$ & 0.015 \\
\hline & Range & $1.917-468.7$ & $69.05-1691$ & $11.24-84.07$ & & \\
\hline \multirow{2}{*}{$\mathrm{BbF}$} & Mean & $96.15 \pm 115.1$ & $565.5 \pm 686.7$ & $16.73 \pm 2.708$ & $1.2 \mathrm{E}-5 \pm 0.000$ & $1.5 \mathrm{E}-4$ \\
\hline & Range & $9.399-293.4$ & $28.52-1720$ & $15.18-22.74$ & & \\
\hline $\mathrm{BkF}$ & Mean & $371.0 \pm 566.1$ & $861.5 \pm 543.7$ & $50.03 \pm 63.38$ & $1.3 \mathrm{E}-4 \pm 0.000$ & $1.5 \mathrm{E}-3$ \\
\hline \multirow{2}{*}{$\mathrm{BaP}$} & Mean & $257.3 \pm 270.5$ & $819.5 \pm 511.0$ & $74.88 \pm 68.70$ & BDL & $1.5 \mathrm{E}-5$ \\
\hline & Range & $7.048-660.8$ & $68.70-1502$ & $20.60-192.4$ & & \\
\hline \multirow{4}{*}{$\begin{array}{l}\mathrm{DbA} \\
\mathrm{IdP}\end{array}$} & Mean & $257.5 \pm 300.7$ & $405.3 \pm 369.2$ & $58.10 \pm 42.80$ & $1.0 \mathrm{E}-6 \pm 0.000$ & $1.5 \mathrm{E}-5$ \\
\hline & Range & $22.50-758.8$ & 113.6-1036 & $22.44-130.4$ & & \\
\hline & Mean & $105.5 \pm 82.55$ & $424.5 \pm 213.7$ & $104.9 \pm 141.3$ & $1.562 \pm 0.890$ & \\
\hline & Range & $16.50-195.3$ & $99.24-687.0$ & $17.65-349.1$ & & \\
\hline tPAHs & & $1344 \pm 1685$ & $4154 \pm 3461$ & $354.7 \pm 360.7$ & $2.574 \pm 0$ & 0.017 \\
\hline
\end{tabular}

The result also showed that the values were far above the USEPA set limit which means their presence in the soil portends danger if necessary actions are not taken. The result is far above works by wang et al., [9] $(0.471 \mathrm{mg} / \mathrm{kg})$, Barránberdón et al., [10] $(0.1384 \mathrm{mg} / \mathrm{kg})$ and Tarafdar and Sinha [11] $(0.044 \mathrm{mg} / \mathrm{kg})$. Others were Dutch $(0.02-0.05 \mathrm{mg} / \mathrm{kg})$, Mexican $(0-6 \mathrm{mg} / \mathrm{kg})$, and Polish $(0.02-10 \mathrm{mg} / \mathrm{kg})$ limits [12] which were all below this work. The high values were a result of mining activities which causes environmental pollution.

\subsection{PAHs Ring Analysis}

The contents of individual PAHs as grouped by ring numbers in the profiles were analyzed which is shown in figures 1 and 2 below.

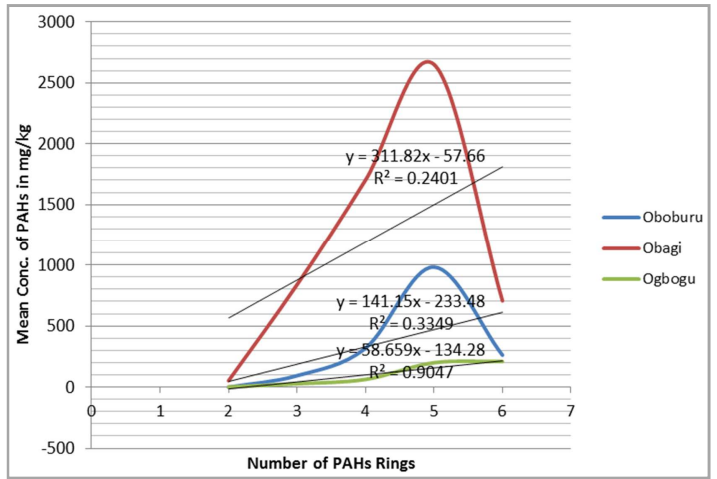

Figure 1. Concentration distributions by PAHs rings in contaminated soil samples of the study area.

The average of individual PAHs as grouped varied by $33 \%$ 
with the rings and the profiles follow an order of 5-ring $>4$ ring $>$ 6-ring $>3$-ring $>2$-ring for Oboburu area. The high average of 5-ring PAHs may be due to the dominant nature of the ring, meaning they were the major pollutant types and their sources to the environment were within the study area. PAHs from Obagi varied by $24 \%$ with the PAH rings. 5-ring was dominant followed by 4-ring, 3-ring, and 6-ring. The samples from Ogbogu indicated that the average values for PAHs differs by $90 \%$ with the rings and 5-ring dominated followed by 4-ring and 3-ring respectively. The overall ring result showed that 5-ring was dominant which might be from the petroleum sources or due to the hydrophobicity property of the high molecular weight PAHs, also because the LMW tends to be biodegradable, high solubility and volatility.

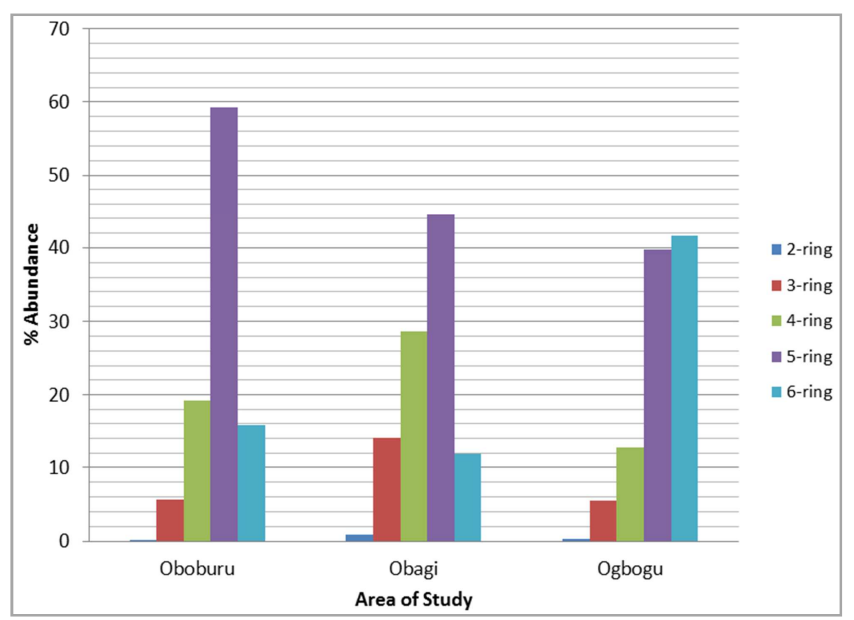

Figure 2. Characteristics of PAHs component on Contaminated soil Samples.

From the figure above, the 5-ring members were more abundant in Oboburu and Obagi. These are BbF, BkF, DbA, and $\mathrm{BaP}$ while for Ogbogu the dominant ring was the 6-ring made up of IdP and $\mathrm{BgP}$. The findings showed that 4-ring and 6-ring made up of $\mathrm{Chr}$, Pyr, Flu and BaA, followed the most dominant PAHs. The 5, 6, and 4-rings are all of high molecular weight PAHs which could have emanated from environmental pollution sources.

\subsection{Source Appointment Using Principal Component Analysis}

The origin of the PAHs found in the environment was checked using principal component analysis and the result is depicted in the table below.

Two principal components were extracted with component 1 accounting for $68.246 \%$ and principal component 2 was $24.393 \%$. The two principal components accounted for $92.639 \%$ of the variation in the observed data set. From component 1, the following PAHs had higher values Phe, Ace, Acn. Pyr, Nap, Ant, Flo, BbF, Flu, Chr, BaA, DbA, and BgP suggesting petrogenic sources like vehicular fumes, petroleum spillages, seepages, etc, while for component 2 , it was $\mathrm{IdP}, \mathrm{BkF}$, and $\mathrm{BaP}$ that gave the highest loading which indicated pyrogenic sources like coal and gas flaring. The compounds $\mathrm{DbA}$, IdP, and $\mathrm{BgP}$ are characteristic of gasoline emissions, while $\mathrm{BbF}, \mathrm{BkF}$, and Phe are the predominant PAH species in diesel emissions [13, 14]. It is therefore, necessary to say that oil and gas mining is a major contributor to the presence of chemicals in the farmlands.

Table 4. Principal Component loadings of PAH in soil sample.

\begin{tabular}{lll}
\hline \multirow{2}{*}{ PAHs } & \multicolumn{2}{l}{ Principal Components } \\
\cline { 2 - 3 } & $\mathbf{1}$ & $\mathbf{2}$ \\
\hline Nap & 0.947 & 0.269 \\
Ace & 0.961 & 0.246 \\
Acn. & 0.874 & 0.092 \\
Flo & 0.908 & 0.354 \\
Phe & 0.962 & 0.247 \\
Ant & 0.901 & 0.383 \\
Flu & 0.898 & 0.404 \\
Pyr & 0.742 & 0.643 \\
BaA & 0.840 & 0.510 \\
Chr & 0.893 & 0.422 \\
BbF & 0.906 & 0.393 \\
BkF & -0.026 & 0.988 \\
BaP & 0.613 & 0.785 \\
DbA & 0.782 & 0.314 \\
IdP & 0.562 & 0.737 \\
BgP & 0.888 & 0.159 \\
Eigen value & 10.919 & 3.903 \\
Loading \% & 68.246 & 24.393 \\
Cumulative \% & 68.246 & 92.639 \\
\hline
\end{tabular}

\subsection{Carcinogenic Risk of Polycyclic Aromatic Hydrocarbons}

Table 5 showed the cancer risk assessment for the respective Egi communities. Children population of Oboburu had a range of $3.28 \mathrm{E}-5$ to $6.17 \mathrm{E}-3$ and adult was $8.18 \mathrm{E}-6$ to 1.54E-3. The total cancer risks were 1.07E-2 for children and 6.69E-3 for adult. BaP (6.17E-3), IdP (2.53E-3) Benzo (k) Flu (8.91E-4), and DaA (6.17E-4) had the highest cancer risk. While for adults were; BaP (1.54E-3), IdP (6.33E-4) BkF (2.23E-4), and DaA (1.55E-4).

Table 5. Carcinogenic risk of PAHs in contaminated soil samples of the study area.

\begin{tabular}{llll}
\hline PAHs & Oboburu & Obagi & Ogbogu \\
\hline & & Children & \\
$\mathrm{BaA}$ & $2.86 \mathrm{E}-4$ & $1.21 \mathrm{E}-3$ & $4.01 \mathrm{E}-5$ \\
$\mathrm{Chr}$ & $3.28 \mathrm{E}-5$ & $1.36 \mathrm{E}-4$ & $7.88 \mathrm{E}-6$ \\
$\mathrm{BbF}$ & $2.31 \mathrm{E}-4$ & $1.36 \mathrm{E}-3$ & $4.01 \mathrm{E}-5$ \\
$\mathrm{BkF}$ & $8.91 \mathrm{E}-4$ & $2.06 \mathrm{E}-3$ & $1.79 \mathrm{E}-4$ \\
$\mathrm{BaP}$ & $6.17 \mathrm{E}-3$ & $1.96 \mathrm{E}-2$ & $1.39 \mathrm{E}-3$ \\
$\mathrm{DbA}$ & $6.17 \mathrm{E}-4$ & $9.71 \mathrm{E}-4$ & $1.39 \mathrm{E}-4$ \\
$\mathrm{IdP}$ & $2.53 \mathrm{E}-3$ & $1.01 \mathrm{E}-2$ & $2.51 \mathrm{E}-3$ \\
$\Sigma \mathrm{PAHs}$ & $1.07 \mathrm{E}-2$ & $3.54 \mathrm{E}-2$ & $4.31 \mathrm{E}-3$ \\
& & Adult & \\
$\mathrm{BaA}$ & $7.17 \mathrm{E}-5$ & $3.04 \mathrm{E}-4$ & $1.02 \mathrm{E}-5$ \\
$\mathrm{Chr}$ & $8.18 \mathrm{E}-6$ & $3.42 \mathrm{E}-5$ & $1.97 \mathrm{E}-6$ \\
$\mathrm{BbF}$ & $5.77 \mathrm{E}-5$ & $3.39 \mathrm{E}-4$ & $1.00 \mathrm{E}-5$ \\
$\mathrm{BkF}$ & $2.23 \mathrm{E}-4$ & $5.17 \mathrm{E}-4$ & $3.00 \mathrm{E}-5$ \\
$\mathrm{BaP}$ & $1.54 \mathrm{E}-3$ & $4.91 \mathrm{E}-3$ & $4.49 \mathrm{E}-4$ \\
$\mathrm{DbA}$ & $1.55 \mathrm{E}-4$ & $2.43 \mathrm{E}-4$ & $3.48 \mathrm{E}-5$ \\
$\mathrm{IdP}$ & $6.33 \mathrm{E}-4$ & $2.54 \mathrm{E}-3$ & $6.29 \mathrm{E}-5$ \\
$\Sigma \mathrm{PAHs}$ & $2.69 \mathrm{E}-3$ & $8.90 \mathrm{E}-3$ & $5.99 \mathrm{E}-4$ \\
\hline
\end{tabular}


The range for Obagi was $1.36 \mathrm{E}-4$ to $1.96 \mathrm{E}-2$ for children and total PAHs was 3.54E-2. Adult had a ranged of 3.42E-5 to $4.91 \mathrm{E}-3$ and total PAHs was $8.90 \mathrm{E}-3$. The estimation indicated that $\mathrm{BaP}$ (1.96E-2), Indeno (1,2,3-cd) Pyr (1.01E-2), $\mathrm{BkF}$ (2.03E-3) and $\mathrm{BbF}$ (1.36E-3) were of high risk values. There were high risk for adult in $\mathrm{BaP}$ (4.91E-3), IdP (2.54E$3), \mathrm{BkF}(5.17 \mathrm{E}-4)$, and $\mathrm{BbF}$ (3.39E-4). Ogbogu had a range of $7.88 \mathrm{E}-6$ to $4.31 \mathrm{E}-3$ for children, $1.97 \mathrm{E}-6$ to $4.49 \mathrm{E}-4$ for adult, while total PAHs risk was $4.31 \mathrm{E}-3$ for children and 5.99E-4 for adult. IdP (2.51E-3), BaP (1.39E-3), BkF (1.79E4) and DaA (1.39E-4) had highest CR values for the children. The adult risk were high for the following PAHs; Benzo (a)
Pyrene (4.49E-4), IdP (6.29E-5), DaA (3.48E-5), and BkF (3.00E-5).

However, across the three study area the highest risk were detected for $\mathrm{BaP}, \mathrm{IdP}, \mathrm{BkF}$ and $\mathrm{BbF}$. The general risks were high compared to the set limit of $10^{-5}$ and $10^{-6}$ risk values. Obagi had the highest risk followed by Oboburu, while Ogbogu was least. This study was higher than the report by Cocarta et al, [15] (2.56E-6), Tarafdar and Sinha [11] (1.77E4 to $9.68 \mathrm{E}-4)$, while Wang et al., [9] (2.19E-4 to 9.68E-4) reported values within the range of this work. Collins et al., [16], stated that a risk of $10^{-5}$ could lead to notification of the public, such could be of danger to inhabitants.

Table 6. Correlation matrix for PAHs in the contaminated soil samples from the study area.

\begin{tabular}{|c|c|c|c|c|c|c|c|c|c|}
\hline & & 1 & 2 & 3 & 4 & 5 & 6 & 7 & 8 \\
\hline 1 & Nap & 1 & & & & & & & \\
\hline 2 & Ace & $0.99 * *$ & 1 & & & & & & \\
\hline 3 & Can & $0.838 * *$ & $0.846^{* *}$ & 1 & & & & & \\
\hline 4 & Flo & $0.964 * *$ & $0.975 * *$ & $0.815 * *$ & 1 & & & & \\
\hline 5 & Phe & $0.991 * *$ & $0.999 * *$ & $0.849 * *$ & $0.980 * *$ & 1 & & & \\
\hline 6 & Ant & $0.947 * *$ & $0.962 * *$ & $0.812 * *$ & $0.940 * *$ & $0.962 * *$ & 1 & & \\
\hline 7 & Flu & $0.982 * *$ & $0.978 * *$ & $0.821 * *$ & $0.987 * *$ & $0.980 * *$ & $0.945 * *$ & 1 & \\
\hline 9 & $\mathrm{BaA}$ & $0.923 * *$ & $0.940 * *$ & $0.784 * *$ & $0.969 * *$ & $0.944 * *$ & $0.971 * *$ & $0.963 * *$ & $0.933 * *$ \\
\hline 10 & Chr & $0.956 * *$ & $0.969 * *$ & $0.819 * *$ & $0.961 * *$ & $0.969 * *$ & $0.995 * *$ & $0.966 * *$ & $0.940 * *$ \\
\hline 11 & $\mathrm{BbF}$ & $0.984 * *$ & $0.979 * *$ & $0.818 * *$ & $0.951 * *$ & $0.976 * *$ & $0.977 * *$ & $0.979 * *$ & $0.945^{* *}$ \\
\hline 12 & $\mathrm{BkF}$ & 0.236 & $0.219 * *$ & 0.11 & 0.324 & 0.219 & 0.376 & 0.37 & $0.624^{*}$ \\
\hline 13 & $\mathrm{BaP}$ & $0.789 * *$ & $0.778 * *$ & $0.601 *$ & $0.839 * *$ & $0.782 * *$ & $0.844 * *$ & $0.869 * *$ & $0.955 * *$ \\
\hline 14 & $\mathrm{DbA}$ & $0.775 * *$ & $0.778 * *$ & $0.633^{*}$ & $0.773 * *$ & $0.785 * *$ & $0.809 * *$ & $0.779 * *$ & $0.789 * *$ \\
\hline 15 & IdP & $0.732 * *$ & $0.709 * *$ & 0.555 & $0.773 * *$ & $0.713 * *$ & $0.726^{* *}$ & $0.811^{* *}$ & $0.872 * *$ \\
\hline
\end{tabular}

Table 6. Continued.

\begin{tabular}{|c|c|c|c|c|c|c|c|c|}
\hline & 9 & 10 & 11 & 12 & 13 & 14 & 15 & 16 \\
\hline \multicolumn{9}{|l|}{1} \\
\hline \multicolumn{9}{|l|}{2} \\
\hline \multicolumn{9}{|l|}{3} \\
\hline \multicolumn{9}{|l|}{4} \\
\hline \multicolumn{9}{|l|}{5} \\
\hline \multicolumn{9}{|l|}{6} \\
\hline \multicolumn{9}{|l|}{8} \\
\hline 9 & 1 & & & & & & & \\
\hline 10 & $0.985^{* *}$ & 1 & & & & & & \\
\hline 11 & $0.954 * *$ & $0.982 * *$ & 1 & & & & & \\
\hline 12 & 0.497 & 0.41 & 0.37 & 1 & & & & \\
\hline 13 & $0.914 * *$ & $0.870 * *$ & $0.857 * *$ & $0.756 * *$ & 1 & & & \\
\hline 15 & $0.809^{* *}$ & $0.773 * *$ & $0.773^{* *}$ & $0.669 * *$ & $0.928 * *$ & $0.698 * *$ & 1 & \\
\hline 16 & $0.795^{* *}$ & $0.843^{* *}$ & $0.833^{* *}$ & 1 & $0.674^{* *}$ & $0.905^{* *}$ & 0.694 & 1 \\
\hline
\end{tabular}

*significant at $5 \%(\mathrm{p}<0.05), * *$ significant at $1 \%(\mathrm{p}<0.01)$.

The correlation matrix indicated significant positive relationship in the levels of all the PAH except between Acn, and $\mathrm{BkF}(\mathrm{r}=0.110, \mathrm{p}>0.05)$, Acn and $\operatorname{IdP}(\mathrm{r}=0.555, \mathrm{p}>0.05)$, Flo and $\operatorname{BkF}(r=0.324, p>0.05)$, Phe and $B k F \quad(r=0.219$, $\mathrm{p}>0.05), \quad \mathrm{BkF}$ and Ant $(\mathrm{r}=0.376, \mathrm{p}>0.05) \quad \mathrm{Flu}$ and $\mathrm{BkF}$ $(\mathrm{r}=0.370, \mathrm{p}>0.05), \mathrm{BkF}$ and $\mathrm{BaA}(\mathrm{r}=0.497, \mathrm{BkF}$ and $\mathrm{Chr}$ $(\mathrm{r}=0.410, \mathrm{p}>0.05), \mathrm{BkF}$ and $\mathrm{BbF}(\mathrm{r}=0.370, \mathrm{p}>0.05)$. This means that $\mathrm{BkF}$ was of no significant relationship with Acn,
Flo, Phe, Ant, BaA, Chr, BbF ( $\mathrm{p}>0.05)$.

\section{Conclusion}

The findings concludes that PAHs in soil from contaminated farmland due to human activities within the study area which includes oil and gas exploration, diesel combustion, petrol combustion, gas flaring, bush burning, 
road construction and others. It also showed high cancer risk due to PAHs via ingestion which may be of concern. We strongly suggest that the relevant authorities and immediate inhabitants should be notified of the danger posed by the discharge of fossil fuel to the area.

\section{Acknowledgements}

The authors wish to show gratitude to department of Pure and Industrial Chemistry for providing the opportunity for this research work and also thank immensely Total Exploitation and Production Nigeria Limited (TEPNL) for their scholarship to ensure the work was concluded.

\section{References}

[1] Singare, P. U. (2015). Studies on polycyclic aromatic hydrocarbons in surface sediments of Mithi River near Mumbai, India: assessment of sources, toxicity risk and biological impact. Material Pollution Bulletin: 101, 232-42.

[2] Inam, E., Owhoeke, E. \& Essien, J. (2014). Human carcinogenic risk assessment of polycyclic aromatic hydrocarbons in freshwater samples from Ogba/Egbema/Ndoni communities in rivers state, Nigeria. Journal of Chemical Society of Nigeria: 39 (2), 15-22.

[3] Li Z, Ma Z, Van der Kuijp T. J., Yuan, Z. and Huang, L. (2014b). A review of soil heavy metal pollution from mines in China: pollution and health risk assessment. Science and Total Environment: 468-469, 843-853.

[4] USEPA (1989) Risk assessment guidance for superfund, vol. I: human health evaluation manual (Part A). I: 291. doi: EPA/540/1-89/002. USEPA, Washington, DC.

[5] USEPA (2004) Risk assessment guidance for superfund (RAGS), vol. I: human health evaluation manual (Part E, supplemental guidance for dermal risk assessment). USEPA, Washington, DC.

[6] USEPA (2009) Risk assessment guidance for superfund, vol. I: human health evaluation manual (Part F, supplemental guidance for inhalation risk assessment). USEPA, Washington, DC.

[7] Emrah, C. (2012). Health risk assessment of trace metals, PAHs and trihalomethanes in drinking water of cankiri, Turkey. E-Journey of Chemistry: 9 (4), 1976-1991.
[8] Adetunde, O. T., Mills, G. A., Olayinka, K. O., and Alo, B. I. (2014). Assessment of occupational exposure to polycyclic aromatic hydrocarbons via involuntary ingestion of soil from contaminated soils in Lagos, Nigeria. Journal of Environmental Science and Health, 49, 1661-1671.

[9] Wang, J., Zhang, X., Ling, W., Liu, R., Liu, J., Kang, F. and Gao, Y. (2016). Contamination and health risk assessment of PAHs in soils and crops bin industrial areas of the Yangtze River Delta region, China, Chemosphere: Doi: 10.1016/j.chemosphere.2016.10.113.

[10] Barrán-Berdón, L. A., González, G. V., Aboytes, P. G., RodeaPalomares, I., Carrillo-Chávez, A., Gómez-Ruiz, H. and Cuéllar, V. B. (2012). Polycyclic aromatic hydrocarbons in soils from a brick manufacturing location in central mexico, Revista Internacional de Contaminacion Ambient: 28 (4), 277288.

[11] Tarafdar, A. and Sinha, A. (2017). Cancer Risk Assessment of Polycyclic Aromatic Hydrocarbons in the Soils and Sediments of India: A Meta-Analysis, Environmental Management: DOI 10.1007/s00267-017-0920-6.

[12] Ray, S., Khillare, P. S., Agarwal, T. and Shridhar, V. (2008). Assessment of PAHs in soil around the International Airport in Delhi, Indian Journal of Hazardous Material: 156, 9-16.

[13] Khalili, N. R., Scheff, P. A. and Holsen, T. M. (1995). PAH source fingerprints for coke ovens, diesel and, gasoline engines, highway tunnels, and wood combustion emissions. Atmosphere and Environment; 29, 533-542.

[14] Kong, S., Ding, X., Bai, Z., Han, B., Chen, L., Shi, J. and Li, Z. (2010). A seasonal study of polycyclic aromatic hydrocarbons in PM2.5 and PM2.5-10 in five typical cities of Liaoning Province, China. Journal of Hazardous Material: $183,70-80$.

[15] Cocarta, M. I., Stoian, A. M. and Badea, A. (2016). Human health risk assessment: a case study involving polycyclic aromatic hydrocarbons soil contamination and human exposure international Journal of Advances in Science, Engineering and Technology: 4 (1), 144-149.

[16] Collins, J F., Brown, J. P., Alexeeff, G. V. and Salmon, A. G. (1998). Potency equivalency factors for some polycyclic aromatic hydrocarbons and polycyclic aromatic hydrocarbon derivatives. Regulatory Toxicology and Pharmacology: 28, 45-54. 